\title{
Effect of Foliar Spraying of Organic and Inorganic Selenium Fertilizers On Selenium Accumulation and Speciation During Different Stages of Rice Growth
}

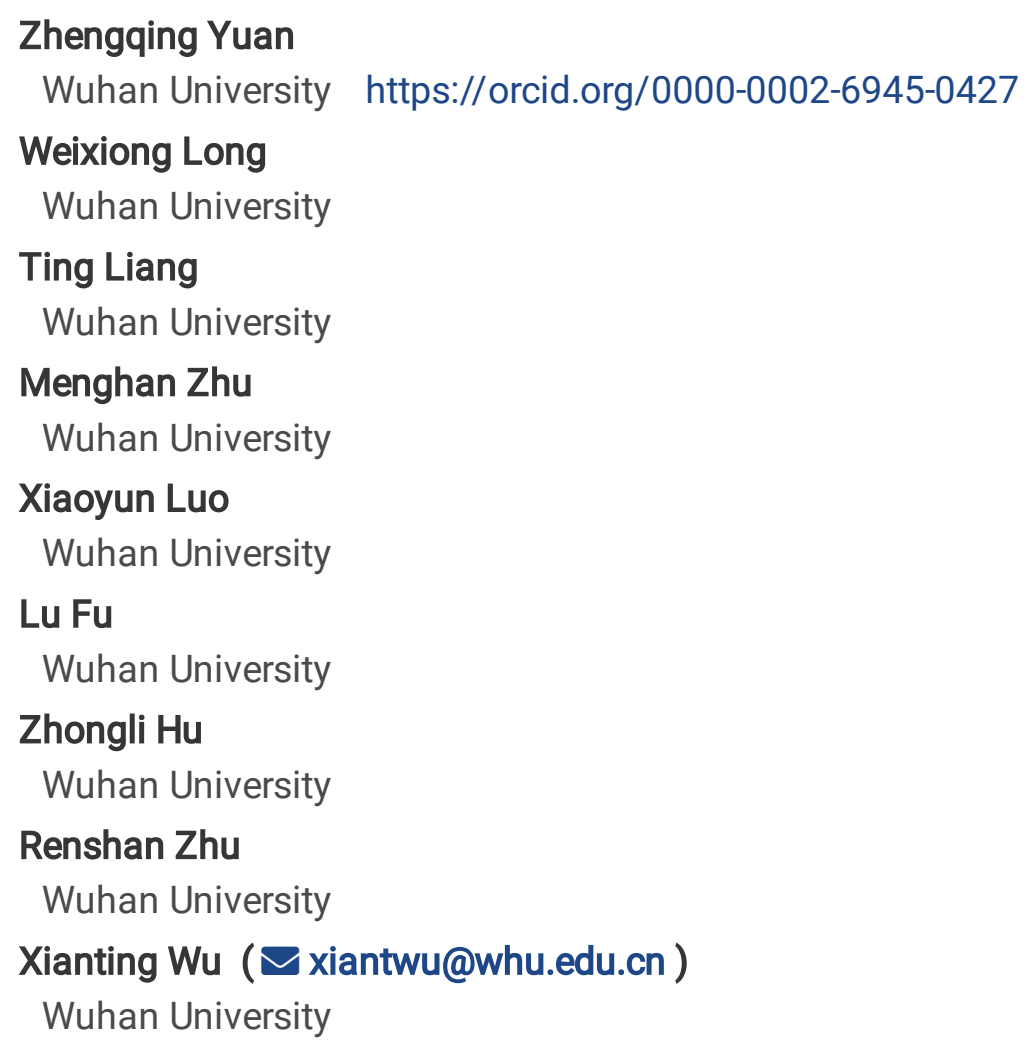

\section{Research Article}

Keywords: Organic selenium, fertilization, selenium speciation, foliar spray

Posted Date: November 9th, 2021

Dol: https://doi.org/10.21203/rs.3.rs-1040038/v1

License: (9) (1) This work is licensed under a Creative Commons Attribution 4.0 International License. Read Full License 


\section{Abstract}

\section{Aims}

Most crops are supplemented with selenium (Se) through the exogenous addition of inorganic selenium fertilizer. There is a lack of in-depth research on organic selenium fertilizers. Meanwhile, the dosage range between human selenium deficiency and selenium toxicity is narrow, so the selenium content of agricultural products needs to be controlled within a reasonable interval.

\section{Methods W}

e analyzed and compared the Se accumulation and speciation in rice during three different growth stages (late tillering stage, initiate heading stage, and full heading stage) using three selenium fertilizers, selenite, fermented Se, and potassium Selenocyanoacetate (Se-AAF) via the foliar application.

\section{Results}

The selenium content in rice sprayed with organic selenium fertilizer was controlled in the relatively safe range and met the human selenium supplement requirement compared to the sprayed sodium selenite, which was too high of a dose. The percentage of organic Se and protein Se in brown rice was found to be similar in all three Se fertilizers. The highest organic selenium content of $91.57 \%$ was found in the grain of rice at the full heading stage by spraying Se-AAF. The main Se species in the grain was selenomethionine (SeMet), which reached $80 \%$ of the total selenium. Se-methyl selenocysteine(SeMeCys) was found only in Se-AAF. The grain quality showed that all three Se fertilizers increased the consistency of gelatinization.

\section{Conclusions}

Appropriately delaying the spraying time and selecting organic Se fertilizer as the Se source can help to produce green and safe selenium-rich rice.

\section{Introduction}

About 500 to one billion people in the world have selenium deficiency (Combs 2001). The US Food and Nutrition Board has proposed a recommended dietary allowance of $55 \mu \mathrm{g} \mathrm{Se} /$ day for accdult humans (Goldhaber 2003; Thiry et al. 2012). However, the intake of selenium in the diet ranges between $7 \mu \mathrm{g} / \mathrm{day}$ and $4990 \mu \mathrm{g} / \mathrm{day}$, which varies greatly around the world (Rayman 2008). The lack of selenium has become an urgent global health problem (Valdiglesias et al. 2010). Crops are the main source of the human intake of selenium. As the staple food crop, selenium content in rice is directly related to the selenium nutritional status of most people. Therefore, increasing Se concentration in rice by applying selenium fertilizer is of great significance for improving the Se nutrition in human beings (Giacosa et al. 2014).

Selenium is an essential trace element for both animals and humans (Schwarz and Foltz 2009). The human body can assimilate selenium to meet normal human needs through the intake of Se-enriched agricultural products. However, the human body has little demand for it, and agricultural products with excessive selenium content can be 
harmful to the human body (Hatfield et al. 2014). Selenium holds a narrow threshold between beneficial and harmful effects on the body, with both inadequate and excessive intake of selenium affecting one's health, which happens at the appropriate dose interval. If the intake is less than $40 \mu \mathrm{g} / \mathrm{day}$, the human body is in a state of selenium deficiency, but if it is more than $400 \mu \mathrm{g} /$ day, it can lead to safety risks and even symptoms of selenium toxicity (Fordyce 2007; Winkel et al. 2012). Therefore, deciding to have selenium as a supplement needs strict control of its amount and time intervals according to its human serum levels. Also, effective measures are needed to reasonably regulate the selenium content in crops within the scientific range. It is not enough to just supplement selenium; it is also important to supplement it reasonably and precisely.

The main methods of selenium biofortification include soil application of selenium and foliar spraying of selenium. Soil application results in significant selenium wastage since $80-95 \%$ of selenate is likely to be lost due to irrigation or rainfall (Keskinen et al. 2011). Also, more than $80 \%$ of selenite is fixed by the soil only for a short term (Liu et al. 2015), with environmental impacts shown after selenium enters the water bodies through surface runoff. Moreover, the success of soil application depends largely on the homogeneity of the physicochemical properties of the soil, including soil structure and soil pH (Hartfiel and Bahners 1988). Foliar spraying eliminates the transportation of selenium from the roots to the ground and transports it directly from the leaves to the grains, which is more bioavailable than soil-applied selenium. The selenium enrichment effect by foliar spray is eight times higher than that of the soil-applied method (Ros et al. 2016). The soil application of selenate results in $70 \%$ of the selenium getting concentrated in the stalk part of rice while less than $18 \%$ enriches the grain (Boldrin et al. 2013). However, the foliar application of selenate enriches the rice grain with $45 \%$ of selenium (Deng et al. 2017). Hence, the foliar spraying method could promote the uptake and accumulation of selenium in the edible part of plants (Fang et al. 2009).

Usually, selenium fertilizer is divided into organic selenium fertilizer and inorganic selenium fertilizer. Among these, inorganic selenium fertilizer is mainly selenite and selenate. Organic selenium fertilizer is mostly compounded with selenium and organic substances such as amino acid chelated selenium fertilizer, humic acid selenium fertilizer, etc. The absorption of inorganic selenium by crops is difficult. Plants can absorb only up to $10 \%$ of selenium from inorganic fertilizers, and the remaining selenium poses a potential threat to the environment (Eich-Greatorex et al. 2007; Wang et al. 2018). With an increase in Se accumulation, an increase is also observed in its soil destructive ability, the amount of harmful heavy metals in the soil, and the soil toxicity. This eventually causes the growth capacity of the plant to be completely lost. Furthermore, when plants absorb inorganic selenium, the product of SeCys and SeMet produce a structure similar to cysteine and methionine, which can be mistakenly integrated into the protein, affecting the formation of disulfide bonds, leading to plant damage (Dumont et al. 2006).

We selected three key stages of rice growth for the selenium foliar spraying experiment, which included later tillering $(\mathrm{LT})$, initiate heading $(\mathrm{IH})$, and full heading $(\mathrm{FH})$ stages. The three selenium fertilizers (selenite, fermented Se, and SeAAF) were compared in terms of total biomass, yield, and total selenium content. To learn more about the accumulation and distribution of selenium in rice plants, we pioneered the field experiment of spraying organic selenium to rice crops. Hydroponics in the laboratory showed that selenite is toxic to plants while our article demonstrated the excellent performance of organic selenium in the field experiment, providing a new idea to improve Se-enriched rice.

\section{Materials And Methods}




\section{Plant materials and phenotypic analysis during seedling treatments}

LY9348 seeds were submerged in $75 \%$ ethanol for 1 min and disinfected with $0.15 \% \mathrm{HgCl}_{2}$ for 1 min. After washing with sterile water six times, the seeds were germinated in Petri dishes in the dark for three days at $37^{\circ} \mathrm{C}$. Next, healthy and uniform seedlings were chosen and soaked in a series of Yoshida solutions ( $1 \mathrm{~L}, 6$ plants per pot) containing 0 , $20 \mu \mathrm{M}$ selenite, and $20 \mu \mathrm{M}$ Se-AAF for 2 weeks. The pH of the solution was adjusted to 5.5 by $\mathrm{HCl}$ or $\mathrm{NaOH}$. Each treatment was replicated in three pots and the solution was changed every three days. Two weeks later, primary root length, shoot length, number of lateral roots, and fresh weight of the shoots were measured.

\section{Field experiments}

A replicated field experiment was conducted in 2018 in two places, Lingshui (18³1'47.1"N $110^{\circ} 03^{\prime} 34.9^{\prime \prime} \mathrm{E}$, Hainan) and Ezhou $\left(30.3756^{\circ} \mathrm{N}, 114.7448^{\circ} \mathrm{E}\right.$, Hubei). The soil properties of Lingshui and Ezhou were as follows: $\mathrm{pH}, 5.75$ and 8.21 ; available nitrogen, $93.4 \mathrm{mg} / \mathrm{kg}$ and $103.9 \mathrm{mg} / \mathrm{kg}$; total selenium, $0.21 \mathrm{mg} / \mathrm{kg}$ and $0.32 \mathrm{mg} / \mathrm{kg}$, respectively. The seeds of rice variety "LY9348" (Oryza sativa L.) were purchased from Guoying Seed Industry Co., Ltd (Wuhan, Hubei, China).

The foliar spray of selenium was applied as selenite, fermented Se, or Se-AAF at $30 \mathrm{~g} \mathrm{ha}^{-1}$. The three Se sources were prepared as $75 \mathrm{mg} \mathrm{L}^{-1}$ solutions and applied to the foliage of rice plants at the late tillering (LT), initial heading $(\mathrm{IH})$, and full heading $(\mathrm{FH})$ stages. The control rice plants $(\mathrm{CK})$ were sprayed with only distilled water. Both in Hainan and Ezhou, the experiment was performed with a randomized complete block design and in three replicates(Table 1). The size of the plot in Hainan was $25 \mathrm{~m}^{2}(5 \mathrm{~m} \times 5 \mathrm{~m})$, and in Ezhou, it was $20 \mathrm{~m}^{2}(4 \mathrm{~m} \times 5 \mathrm{~m})$.

Paddy transplantation, irrigation, and other rice farming practices were carried out based on the farmers' experience. The transplanting dates were February 2, 2018, and June 18, 2018, while the harvest dates were May 18, 2018, and September 25, 2018, in Hainan and Ezhou, respectively.

Table 1 The details of Se foliar spray experiments conducted in Hainan and Ezhou during 2018. 


\begin{tabular}{|c|c|c|c|c|c|c|c|c|}
\hline & $\begin{array}{l}\text { Sowing date } \\
\text { and } \\
\text { transplanting } \\
\text { date }\end{array}$ & Foliar sp & ay date & & $\begin{array}{l}\text { Harvesting } \\
\text { date }\end{array}$ & $\begin{array}{l}\text { Plant } \\
\text { number } \\
\text { and } \\
\text { size of } \\
\text { one } \\
\text { plot }\end{array}$ & Se applied & $\begin{array}{l}\text { Se } \\
\text { working } \\
\text { fluid }\end{array}$ \\
\hline Hainan & $\begin{array}{l}\text { Jan. 2nd, } \\
2018 \\
\text { Feb. 2nd, } \\
2018\end{array}$ & $\begin{array}{l}\text { Mar. } \\
5 \text { th, } \\
2018 \\
\text { Late } \\
\text { tillering } \\
\text { stage }\end{array}$ & $\begin{array}{l}\text { Mar. } \\
16 \text { th, } \\
2018 \\
\text { Initiate } \\
\text { heading } \\
\text { stage }\end{array}$ & $\begin{array}{l}\text { Apr. 17th, } \\
2018 \\
\text { Full } \\
\text { heading } \\
\text { stage }\end{array}$ & $\begin{array}{l}\text { May 18th, } \\
2018\end{array}$ & $\begin{array}{l}576 \\
\text { plants } \\
5 \mathrm{~m} \times 4 \\
\mathrm{~m}\end{array}$ & $\begin{array}{l}30 \mathrm{~g} \mathrm{ha}^{-1} \\
\text { 1) Selenite } \\
\text { 2)Fermented- } \\
\text { Se } \\
\text { 3) Se-AAF }\end{array}$ & $\begin{array}{l}75 \mathrm{mg} \\
\mathrm{L}^{-1}\end{array}$ \\
\hline Ezhou & $\begin{array}{l}\text { May 22nd } \\
\text {,2018 } \\
\text { Jun. 18th } \\
\text { 2018 }\end{array}$ & $\begin{array}{l}\text { Jul. } \\
20 \text { th, } \\
2018 \\
\text { Late } \\
\text { tillering } \\
\text { stage }\end{array}$ & $\begin{array}{l}\text { Jul. } \\
28 \text { th, } \\
2018 \\
\\
\text { Initiate } \\
\text { heading } \\
\text { stage }\end{array}$ & $\begin{array}{l}\text { Aug.24th, } \\
2018 \\
\text { Full } \\
\text { heading } \\
\text { stage }\end{array}$ & $\begin{array}{l}\text { Sep. 25th, } \\
2018\end{array}$ & $\begin{array}{l}500 \\
\text { plants } \\
4 \mathrm{~m} \times 4 \\
\mathrm{~m}\end{array}$ & & \\
\hline
\end{tabular}

\section{Sample preparation}

Eight rice plants were selected randomly from each plot and divided into four parts, including root, shoot, spike axis, and grain. After washing with distilled water, each part of the rice plant was oven-dried at $60^{\circ} \mathrm{C}$ to obtain a constant weight and subsequently grounded into powder for measurement of the selenium content.

Three regions were randomly selected from each plot, and grains from 15 rice plants belonging to each region were sampled. After mixing, the husk was removed to separate the brown rice, whose selenium content was measured. Additionally, the protein from the brown rice was extracted, and its selenium concentration was measured. Later, the grain yield and total biomass from additional 100 rice plants per plot were also measured.

\section{Measurement of Se concentration}

The rice samples were digested by adding $\mathrm{HNO}_{3}-\mathrm{HClO}_{4}($ Volume ratio $=9: 1)$, with the temperature being maintained at approximately $180^{\circ} \mathrm{C}$. The digested solution was restored with $6 \mathrm{~mol} \mathrm{~L}^{-1} \mathrm{HCl}$, cooled, and filtered at a set volume.

Organic selenium concentration was determined using the cyclohexane extraction method (Sun et al. 2013). The obtained data indicated inorganic selenium concentration; however, the organic selenium concentration could be obtained indirectly by subtracting the inorganic selenium content from the total selenium content.

To determine the protein Se concentration, $30.00 \mathrm{~g}$ of brown rice flour was first weighed and added to a $250 \mathrm{~mL}$ Erlenmeyer flask, to which $150 \mathrm{~mL}$ of $0.2 \% \mathrm{NaOH}$ (aq) (brown rice powder and sodium hydroxide solution at a ratio of 1:5) was added. The solution was then stirred with the glass rod evenly and placed on a shaker at $40^{\circ} \mathrm{C}$. After shaking for $1 \mathrm{~h}$ at $100 \mathrm{rpm}$, the solution was centrifuged at $3800 \mathrm{rpm}$ for $10 \mathrm{~min}$. Then, the supernatant was collected, and the step was repeated to extract the complete protein. The two supernatants were pooled together, and $0.1 \mathrm{M} \mathrm{HCl}$ was added to it. The $\mathrm{pH}$ was adjusted to an isoelectric point of 4.8 (Souza et al. 2016). The mixture was placed in a refrigerator for $1 \mathrm{~h}$ at $4^{\circ} \mathrm{C}$ and centrifuged at $3800 \mathrm{rpm}$ for $15 \mathrm{~min}$ at $4^{\circ} \mathrm{C}$. The obtained white precipitate was the protein which was washed thrice with distilled water and centrifuged at $4000 \mathrm{rpm}$ for 5 min to remove the 
impurities. Later, the precipitate was put in an oven (AFD-270L-200, AoFeiDa Instrument and Equipment Co.,230 Ltd., China) and baked for $36 \mathrm{~h}$ at $30^{\circ} \mathrm{C}$.

The Se concentration in the filtrate was measured using hydride generation-atomic fluorescence spectrometry (AFS230E, Kechuanghaiguang Instruments Co., Beijing, China). The soil pH, alkali nitrogen, and total selenium concentration were commissioned by the Hubei Provincial Geological Experimental Testing Center. The instrument used was AFS-820.

The selenium speciation analysis of brown rice was conducted as follows: The brown rice was first hydrolyzed using protease XIV and cellulase for $18 \mathrm{~h}$ in a $37^{\circ} \mathrm{C}$ water bath. The protein was extracted using a methanol-chloroformwater three-phase extractant while the separation was performed using high-performance liquid chromatography (HPLC, SHIMADZU-LC-20AT) and analyzed using an inductively coupled plasma mass spectrometer (ICP-MS, Fisher series X2). The selenium standards were as follows: SeMet, SeCys 2 , SeMeCys, $\mathrm{Se}^{4+}$ and Se ${ }^{6+}$. More details are described in other studies (Bañuelos et al. 2012).

\section{Determination of the characteristics of the grain quality}

To determine the amylose content (AC), gelatinization consistency (GC), gelatinization temperature (GT), and alkali spreading value (ASV), the brown rice powdered samples were scanned using the Near-Infrared Grain Analyzer Perten DA7250. The instrument was switched on for preheating. After calibrating with the reference standard plate, the powdered sample was put into the sample cup; the surface was scratched and placed on the sample stage of the spectrometer for scanning. Note that the sample volume was constant each time, and the test was repeated twice with each sample. According to the accuracy requirements, the average value for the samples was calculated if the ratio of the difference between the two tests resulted in an average value of less than $2 \%$. If the requirements were not met, the samples were re-tested, and the average value was calculated.

The Amino Acid (AA) Content Assay Kit (AKAM001M) and DPPH Free Radical Scavenging Capacity Assay Kit (A153-1-1) were purchased from the Bioxbio and Nanjing Jiancheng, respectively.

\section{Calculation methods}

The Se recovery efficiency (\%) of the whole plant and Se recovery efficiency (\%) of the brown rice were based on the plant Se uptake. More details are described in studies of (Deng et al. 2017).

\section{Statistical analysis}

The statistical analysis was performed using GenStat 18 (18th Edition, VSN International Ltd., Hemel Hempstead, UK) and SPSS 20.0. The data were presented as mean \pm standard error (SE). The mean values were compared using the Least Significant Difference test at the 0.05 level of probability. The Principle component analysis (PCA), partial least squares-discriminate analysis (PLS-DA), and variable importance in projection (VIP) were conducted using the “Statistical Analysis” module on MetaboAnalyst (Xia and Wishart 2011).

\section{Results}

\section{The hydroponics experiment conducted for different Se treatments}


To investigate whether the organic selenium fertilizer was toxic to the seedling stage. Without adding exogenous selenium, the average primary root length of rice was $5.2 \mathrm{~cm}$ after culturing for two weeks. Upon addition of $20 \mu \mathrm{M}$ selenite, the growth of rice was strongly inhibited (Table 2), shortening the length of the root to an average of $3 \mathrm{~cm}$. Also, the total number of lateral roots increased significantly to an average number of three compared to the control. The length of the seedlings became significantly shorter, dropping nearly to $4 \mathrm{~cm}$. The fresh weight of the aerial part was reduced by 1.5 times compared to the control. However, upon culturing rice with $20 \mu \mathrm{M}$ Se-AAF, no difference was observed in terms of the root length, shoot length, shoot fresh weight, and the number of lateral roots compared to the control, indicating no inhibition on the growth of rice plant.

Table 2 Comparison among 0, $20 \mu \mathrm{M}$ selenite sodium, and $20 \mu \mathrm{M}$ Se-AAF fertilizers in the nutrient solution after 2 weeks of Se exposure experiment in LY9348 rice.

\begin{tabular}{|lllll|}
\hline Treatment & Root length(cm) & Lateral root number & Shoot length(cm) & Shoot weight(mg FW) \\
\hline CK & $5.16 \pm 0.24^{\mathrm{a}}$ & $7.89 \pm 0.56^{\mathrm{b}}$ & $15.94 \pm 0.52^{\mathrm{a}}$ & $61.72 \pm 2.05^{\mathrm{a}}$ \\
\hline Selenite & $3.04 \pm 0.22^{\mathrm{b}}$ & $10.94 \pm 0.58^{\mathrm{a}}$ & $12.42 \pm 0.57^{\mathrm{b}}$ & $42.11 \pm 2.92^{\mathrm{b}}$ \\
\hline Se-AAF & $5.51 \pm 0.17^{\mathrm{a}}$ & $8.61 \pm 0.58^{\mathrm{b}}$ & $16.52 \pm 0.54^{\mathrm{a}}$ & $62.72 \pm 2.71^{\mathrm{a}}$ \\
\hline Different letters indicate significant differences $(P<0.05)$. Data are represented as means $\pm S E(n=18)$ \\
\hline
\end{tabular}

The above phenotypic data were used for PCA and PLS-DA analysis (Fig. 1). The sample dots in Fig. 2b were discriminated by $\mathrm{PC} 1$, accounting for $95.1 \%$ of the variation along with showing separate clustering trends among CK, $20 \mu \mathrm{M}$ Se-AAF, and $20 \mu \mathrm{M}$ selenite. The treatments were distributed almost separately on the first component (Fig. 2a). Moreover, component 1 suggested similar seedling traits between CK and $20 \mu \mathrm{M}$ Se-AAF treatment. The high concentration of organic selenium exhibited no toxic to rice at seedling stage. Additionally, based on the values of the variable importance in the projection (VIP) of Component 1, we chose a relatively stringent level of VIP cutoff of 1.0 and found that the shoot weight (fresh weight) suffered serious impact when treated with $20 \mu \mathrm{M}$ selenite. The toxic effect of selenite was mainly manifested in the aerial part of the plants.

\section{Grain yield and the total biomass}

Without selenium fertilizer, the total yield and total biomass were found to be $8.09 \mathrm{t} \mathrm{ha}^{-1}$ and $16.06 \mathrm{t} \mathrm{ha}^{-1}$ in Hainan and $7.52 \mathrm{t} \mathrm{ha}^{-1}$ and $16.59 \mathrm{t} \mathrm{ha}^{-1}$ in Ezhou. Although the kind of selenium fertilizer being sprayed on the plant does not affect the yield, spraying with Se-AAF is shown to increase the total biomass by $9.8 \%$. An interaction was observed between selenium and the environment in the case of total biomass (Table 3 ).

Table 3 Grain yield and total biomass of rice upon foliar spraying of selenite, fermented Se, or Se-AAF during late tillering, (LT) initiate heading $(\mathrm{IH})$ or full heading $(\mathrm{FH})$ stages. 


\begin{tabular}{|c|c|c|}
\hline Treatment & Grain yield $\left(t \mathrm{ha}^{-1}\right)$ & Total biomass $\left(\mathrm{t} \mathrm{ha}^{-1}\right)$ \\
\hline \multicolumn{3}{|l|}{ Se source (S) } \\
\hline CK & 7.95 & 16.19 \\
\hline Selenite & 7.84 & 16.68 \\
\hline Fermented Se & 7.66 & 16.03 \\
\hline Se-AAF & 8.05 & 17.78 \\
\hline $\operatorname{LSD}(P=0.05)$ & NS & 1.45 \\
\hline \multicolumn{3}{|c|}{ Growth stage (G) } \\
\hline LT & 7.95 & 16.50 \\
\hline $\mathrm{IH}$ & 8.02 & 17.20 \\
\hline $\mathrm{FH}$ & 7.63 & 16.45 \\
\hline $\operatorname{LSD}(P=0.05)$ & NS & NS \\
\hline \multicolumn{3}{|l|}{ Environment (E) } \\
\hline Hainan & 8.38 & 17.21 \\
\hline Ezhou & 7.26 & 16.12 \\
\hline $\operatorname{LSD}(P=0.05)$ & 0.29 & 1.03 \\
\hline$S \times G$ & NS & NS \\
\hline$S \times E$ & NS & * \\
\hline$E \times G$ & NS & * \\
\hline$S \times E \times G$ & NS & NS \\
\hline \multicolumn{3}{|c|}{ NS indicates not significant. } \\
\hline * Significant at & 5. & \\
\hline
\end{tabular}

\section{Total selenium, organic selenium, and protein selenium concentrations and proportions in brown rice}

Upon spraying of selenium fertilizer during the LT stage, the selenium content of the brown rice was found to be higher than that of the husk. However, upon delaying the selenium spraying time, an increase was observed in the overall selenium level in both brown rice and husk, with the Se concentration in the husk showing a greater increase, which indicates a decrease in the distribution of selenium in brown rice by delaying the selenium spray. Irrespective of the kind of selenium fertilizer being sprayed, delaying the selenium spray accounted for more than $70 \%$ of the brown rice's selenium content.

Similar to the results of total Se, the organic Se and protein Se content in brown rice also showed a gradual increase in its content with a delay in selenium spraying. Interestingly, although the selenium content in selenite sprayed 
plants was about twice the amount compared to the organic selenium fertilizer spray, no significant differences were found in the percentage, although the organic Se percentages reached at least $85 \%$. It is worth mentioning that when selenium fertilizer was sprayed during the FH stage, the organic Se ratio of Se-AAF reached up to 91.57\%(Table 4). Protein selenium also behaved similarly; however, the lowest protein selenium content was found upon spraying selenium during the $\mathrm{FH}$ stage. The proportion reached up to 34\% (protein Se) regardless of the Se source or spraying stage.

Table 4 Organic Se and protein Se concentrations and proportions at late tillering (LT), initiate heading (IH), or full heading $(\mathrm{FH})$ stages when sprayed with selenium fertilizer.

\begin{tabular}{|c|c|c|c|c|}
\hline Treatment & $\begin{array}{l}\text { Organic Se } \\
\left(\mathrm{mg} \mathrm{kg}^{-1}\right)\end{array}$ & Proportion(\%) & $\begin{array}{l}\text { Protein Se } \\
\left(\mathrm{mg} \mathrm{kg}^{-1}\right)\end{array}$ & Proportion(\%) \\
\hline \multicolumn{5}{|c|}{ Se source-Growth stage (SG) } \\
\hline Selenite-LT & 0.279 & 89.79 & 0.1339 & 43.02 \\
\hline Selenite-IH & 0.664 & 90.66 & 0.3085 & 41.54 \\
\hline Selenite-FH & 0.806 & 89.51 & 0.3290 & 37.22 \\
\hline Fermented Se-LT & 0.141 & 87.15 & 0.072 & 44.45 \\
\hline Fermented Se-IH & 0.267 & 86.81 & 0.1452 & 47.06 \\
\hline Fermented Se-FH & 0.345 & 88.41 & 0.1492 & 39.36 \\
\hline Se-AAF-LT & 0.135 & 85.21 & 0.0704 & 45.13 \\
\hline Se-AAF-IH & 0.242 & 86.23 & 0.1122 & 39.51 \\
\hline Se-AAF-FH & 0.388 & 91.57 & 0.1479 & 34.70 \\
\hline $\operatorname{LSD}(P=0.05)$ & 0.1769 & 4.33 & 0.0834 & 6.95 \\
\hline \multicolumn{5}{|l|}{ Environment (E) } \\
\hline Hainan & 0.415 & 87.11 & 0.195 & 41.17 \\
\hline Ezhou & 0.311 & 89.63 & 0.131 & 41.50 \\
\hline $\operatorname{LSD}(P=0.05)$ & 0.14 & 2.09 & 0.058 & 3.69 \\
\hline$S G \times E$ & NS & NS & NS & NS \\
\hline
\end{tabular}

\section{Se speciation in brown rice}

Since the highest selenium content was found during the $\mathrm{FH}$ stage, we selected brown rice from this stage to determine the selenium speciation. The HPLC-ICP-MS chromatogram is shown in Fig. 3. As shown in Fig. 4, upon no addition of exogenous selenium, three selenium forms were found in brown rice, including SeMet, with a proportion of $62.71 \%$, followed by SeCys 2 with a proportion of $28.83 \%$. After treating with selenium fertilizer, the proportion of each selenium speciation changed, increasing the SeMet content by about $20 \%$ while decreasing the 
proportion of SeCys2 to 11.88\%, 5.90\%, and 9.79\% in selenite, fermented Se, and Se-AAF fertilizer sprayed plants, respectively. Also, the proportion of $\mathrm{Se}^{4+}$ showed a significant decrease. We found the presence of $\mathrm{Se}^{6+}$ in brown rice treated with selenium fertilizer and detected different unknown selenium compounds as well. It is interesting that the presence of SeMeCys was found only in brown rice under Se-AAF treatment at a percentage of $5.23 \%$. Hence, the selenium source could significantly influence its form within brown rice.

\section{The grain quality characteristics and percentage recommended daily allowance of LY9348}

The analysis of the grain quality characteristics showed that there was no regular change in the grain quality between the type of selenium fertilizer used or the time at which selenium was sprayed(Table 5). However, the addition of exogenous selenium generally improved the gelatinization consistency. We used the recommended daily allowance (RDA) of Se for adults as an index. The RDA provided by $50 \mathrm{~g}$ of brown rice is shown in Table 6. The control plants were found to have only $5 \%$ selenium content (no selenium applied), which is not enough to provide the amount of daily intake of selenium. The RDA was significantly improved by spraying exogenous selenium(Table 6).

Table 5 The grain quality characteristics of LY9348 at different growth stages sprayed with different selenium fertilizers.

\begin{tabular}{|c|c|c|c|c|c|}
\hline Treatments & $\mathrm{AC}(\%)$ & $\mathrm{GC}(\mathrm{mm})$ & GT (ASV) & $A A\left(\mu g g^{-1}\right)$ & $\begin{array}{l}\text { Antioxidant activity (\% } \\
\text { inhibition) }\end{array}$ \\
\hline Selenite-LT & $26.59 \pm 0.44^{\mathrm{bc}}$ & $84.06 \pm 0.78^{b}$ & $2.37 \pm 0.17^{c}$ & $11.83 \pm 0.74^{c}$ & $47.37 \pm 1.27^{a}$ \\
\hline $\begin{array}{l}\text { Fermented Se- } \\
\text { LT }\end{array}$ & $26.32 \pm 0.62^{\mathrm{bcd}}$ & $84.70 \pm 2.74^{b}$ & $3.09 \pm 0.18^{a}$ & $14.10 \pm 0.41^{a}$ & $42.55 \pm 0.57^{\mathrm{bcd}}$ \\
\hline Se-AAF-LT & $27.54 \pm 0.95^{\mathrm{ab}}$ & $88.47 \pm 2.95^{\mathrm{a}}$ & $2.38 \pm 0.11^{b c}$ & $9.81 \pm 0.21^{d}$ & $42.39 \pm 0.52^{\mathrm{bcd}}$ \\
\hline Selenite-IH & $26.03 \pm 0.62^{\mathrm{cd}}$ & $81.38 \pm 0.42^{b}$ & $2.60 \pm 0.11^{b}$ & $11.95 \pm 0.21^{c}$ & $44.38 \pm 2.22^{b}$ \\
\hline $\begin{array}{l}\text { Fermented Se- } \\
\mathrm{IH}\end{array}$ & $25.15 \pm 0.09^{d}$ & $77.86 \pm 1.74^{\mathrm{C}}$ & $1.80 \pm 0.12^{\mathrm{e}}$ & $12.67 \pm 0.21^{b c}$ & $40.69 \pm 1.53^{c d}$ \\
\hline Se-AAF-IH & $27.17 \pm 1.33^{a b c}$ & $89.57 \pm 0.86^{a}$ & $2.45 \pm 0.09^{b c}$ & $13.02 \pm 0.90^{b}$ & $45.60 \pm 2.64^{\mathrm{ab}}$ \\
\hline Selenite-FH & $26.22 \pm 0.50^{\mathrm{bcd}}$ & $88.47 \pm 1.22^{a}$ & $2.27 \pm 0.08^{d c}$ & $8.86 \pm 0.36^{e}$ & $42.74 \pm 1.11^{\mathrm{bcd}}$ \\
\hline $\begin{array}{l}\text { Fermented Se- } \\
\mathrm{FH}\end{array}$ & $28.17 \pm 0.17^{a}$ & $90.98 \pm 1.39^{a}$ & $2.24 \pm 0.10^{\mathrm{dc}}$ & $12.55 \pm 0.90^{\mathrm{bc}}$ & $41.14 \pm 1.30^{\mathrm{cd}}$ \\
\hline Se-AAF-FH & $27.59 \pm 0.33^{\mathrm{ab}}$ & $90.32 \pm 0.26^{a}$ & $2.22 \pm 0.16^{d c}$ & $10.05 \pm 0.21^{d}$ & $39.60 \pm 0.18^{d}$ \\
\hline CK & $26.53 \pm 1.05^{\mathrm{bc}}$ & $74.57 \pm 3.30^{d}$ & $2.10 \pm 0.04^{d}$ & $13.14 \pm 0.62^{b}$ & $43.39 \pm 0.79^{b c}$ \\
\hline
\end{tabular}

AC: amylose content; GC: gelatinization consistency; GT: gelatinization temperature; ASV: alkali spreading value; Different letters indicate significant differences $(P<0.05)$. Data are represented as means $\pm S E(n=3)$. 
Table 6 Overall Se concentration and percentage recommended daily allowance (\%RDA) in $50 \mathrm{~g}$ of brown rice.

\begin{tabular}{|c|c|c|}
\hline Type & $\begin{array}{l}\text { Brown rice selenium } \\
\left(\mu \mathrm{gg}^{-1}\right)\end{array}$ & $\begin{array}{l}\text { \% RDA from } \\
50 \mathrm{~g}\end{array}$ \\
\hline Selenite-LT & 310 & 28 \\
\hline Selenite-IH & 733 & 67 \\
\hline Selenite-FH & 907 & 82 \\
\hline Fermented Se-LT & 163 & 15 \\
\hline Fermented Se-IH & 306 & 28 \\
\hline Fermented Se-FH & 391 & 36 \\
\hline Se-AAF-LT & 158 & 14 \\
\hline Se-AAF-IH & 286 & 26 \\
\hline Se-AAF-FH & 423 & 38 \\
\hline $\mathrm{CK}$ & 58 & 5 \\
\hline
\end{tabular}

\section{Selenium concentration/distribution in different parts of rice plants and Pearson's correlation analysis}

Under normal conditions, the Se concentration in different rice parts followed a decreasing pattern and is as follows: root $\square$ shoot $\square$ spike axis $\square$ grain. The selenium content in the grain was found to be as low as $0.05 \mathrm{mg} \mathrm{kg}^{-1}$. After spraying the selenium fertilizer, the Se content of the grain was greatly increased, with the highest content being increased by 20 times. Table 7 shows that no matter whether it is shoot, spike axis, or grains, the selenium content order is $\mathrm{LT}<\mathrm{HH}<\mathrm{FH}$, except the root, which uniformly shows the highest Se concentration during the initial heading stages. The Se concentration in the grains during the FH stage was at least 2.7 times the concentration found at the LT stage, regardless of the selenium fertilizer used.

With the soil-based selenium, Pearson's correlation analysis indicated the correlations among root, shoot, spike axis, and grain to be $0.964,0.932$, and 0.22 , respectively, showing a decreasing trend (Table 8 ). Upon foliar spraying with selenium, the correlations among root, shoot, spike axis, and grain were found to be $0.272,0.721$, and 0.834 , respectively, showing an increasing trend (Table 9).

Table 7 Selenium concentration in different parts of rice with foliar spraying of selenite, fermented Se, or Se-AAF at late tillering $(\mathrm{LT})$, initiate heading $(\mathrm{IH})$, or full heading $(\mathrm{FH})$ stages. 


\begin{tabular}{|c|c|c|c|c|}
\hline Treatment & $\begin{array}{l}\text { Roots } \\
\left(\mathrm{mg} \mathrm{kg}^{-1}\right)\end{array}$ & $\begin{array}{l}\text { Straw } \\
\left(\mathrm{mg} \mathrm{kg}^{-1}\right)\end{array}$ & $\begin{array}{l}\text { Spike axis } \\
\left(\mathrm{mg} \mathrm{kg}^{-1}\right)\end{array}$ & $\begin{array}{l}\text { Grains } \\
\left(\mathrm{mg} \mathrm{kg}^{-1}\right)\end{array}$ \\
\hline \multicolumn{5}{|c|}{ Se source-Growth stage (SG) } \\
\hline Selenite-LT & 0.442 & 0.367 & 0.247 & 0.306 \\
\hline Selenite-IH & 0.668 & 0.55 & 0.367 & 0.553 \\
\hline Selenite-FH & 0.379 & 0.927 & 1.059 & 1.041 \\
\hline Fermented Se-LT & 0.416 & 0.258 & 0.128 & 0.148 \\
\hline Fermented Se-IH & 0.479 & 0.472 & 0.19 & 0.274 \\
\hline Fermented Se-FH & 0.343 & 0.605 & 0.414 & 0.413 \\
\hline Se-AAF-LT & 0.362 & 0.299 & 0.137 & 0.123 \\
\hline Se-AAF-IH & 0.719 & 0.695 & 0.379 & 0.267 \\
\hline Se-AAF-FH & 0.338 & 0.898 & 0.781 & 0.393 \\
\hline $\operatorname{LSD}(P=0.05)$ & 0.2206 & 0.3966 & 0.2962 & 0.2446 \\
\hline \multicolumn{5}{|l|}{ Environment (E) } \\
\hline Hainan & 0.574 & 0.695 & 0.474 & 0.441 \\
\hline Ezhou & 0.347 & 0.432 & 0.349 & 0.341 \\
\hline $\operatorname{LSD}(P=0.05)$ & 0.1036 & 0.2024 & 0.2068 & 0.1785 \\
\hline$S G \times E$ & NS & NS & NS & NS \\
\hline NS indicates not & ificant. & & & \\
\hline
\end{tabular}

Table 8 Pearson's correlation coefficients in different parts of LY9348 rice plant without foliar spraying of selenium.

\begin{tabular}{|lllll|}
\hline Organs & Root & Shoot & Spike axis & Grain \\
\hline Root & 1 & & & \\
\hline Shoot & $0.897 * \star$ & 1 & & \\
\hline Spike axis & 0.066 & 0.187 & 1 & 1 \\
\hline Grain & $0.964^{* *}$ & $0.932^{\star *}$ & 0.22 & \\
\hline$* * p<0.01$ (two-tailed). & & & \\
\hline
\end{tabular}

Table 9 Pearson's correlation coefficients in different parts of LY9348 when sprayed with selenium fertilizer. 


\begin{tabular}{|lllll|}
\hline Organs & Root & Shoot & Spike axis & Grain \\
\hline Root & 1 & & & \\
\hline Shoot & $0.391^{* \star}$ & 1 & & \\
\hline Spike axis & 0.152 & $0.809 * \star$ & 1 & 1 \\
\hline Grain & $0.272 *$ & $0.721^{\star *}$ & $0.834 * \star$ & \\
\hline${ }^{*} \mathrm{p}<0.05$ (two-tailed). & & & \\
\hline${ }^{* *} \mathrm{p}<0.01$ (two-tailed). & & & \\
\hline
\end{tabular}

Upon spraying fermented Se and Se-AAF, the correlation coefficient increased among root, shoot, spike axis, and grain. The peak value of the spike axis and grain was 0.962 and 0.971 , respectively. However, the trends observed in various changes were totally different upon spraying selenite, which showed an initial increase and followed by a decline. The correlation coefficient of spike axis-grain was only 0.885 (Table 10).

Table 10 Pearson's correlation coefficient of grain with root, shoot, and spike axis when sprayed with selenite, fermented Se, or Se-AAF.

\begin{tabular}{|c|c|c|c|c|c|}
\hline Se fertilizer & Organs & Root & Shoot & Spike axis & Grain \\
\hline Selenite & \multirow[t]{3}{*}{ Grain } & 0.346 & $0.942^{\star \star}$ & $0.885^{\star \star}$ & 1 \\
\hline Fermented SE & & 0.25 & $0.954^{\star \star}$ & $0.962^{\star \star}$ & 1 \\
\hline Se-AAF & & 0.399 & $0.838 * *$ & $0.971 * \star$ & 1 \\
\hline
\end{tabular}

\section{Recovery efficiency of Se in the whole plant and brown rice}

The Se recovery of selenite at each stage was higher than that of the organic Se fertilizer. The ranking of Se recovery of brown rice was selenite $₫$ Se-AAF $\square$ fermented Se during the FH stage. Maintaining the same Se sources, the Se recovery efficiency of the whole plant and brown rice was increased by delaying the selenium spraying time. Among them, the whole-plant Se recovery using the fermented Se at the FH stage was 4.56 times higher than that found at the LT stage while the Se recovery of the brown rice at the FH stage was 4.81 times higher than that found at the LT stage, indicating a significant effect of varying time in selenium spraying on the Se recovery(Table 11).

Table 11 The recovery efficiency of Se in the whole plant and brown rice with foliar spraying of selenite, fermented Se, or Se-AAF at the LT, IH, or FH stages. 


\begin{tabular}{|lll|}
\hline Treatment & \multicolumn{1}{c|}{$\begin{array}{l}\text { Whole plant Se } \\
\text { Recovery efficiency (\%) }\end{array}$} & Brown rice Se Recovery efficiency (\%) \\
\hline Se source-Growth stage (SG) & 3.92 \\
\hline Selenite-LT & 11.8 & 12.14 \\
\hline Selenite-IH & 21.6 & 15.32 \\
\hline Selenite-FH & 41.6 & 1.97 \\
\hline Fermented Se-LT & 4.3 & 4.39 \\
\hline Fermented Se-IH & 9.9 & 4.86 \\
\hline Fermented Se-FH & 19.6 & 1.71 \\
\hline Se-AAF-LT & 5.9 & 4.65 \\
\hline Se-AAF-IH & 15.9 & 8.22 \\
\hline Se-AAF-FH & 21.2 & 5.875 \\
\hline LSD (P = 0.05) & 12.51 & \\
\hline Environment (E) & & 9.32 \\
\hline Hainan & 16.1 & 3.39 \\
\hline Ezhou & 17.7 & 3.135 \\
\hline LSD (P = 0.05) & 8.03 & NS \\
\hline SG $\times E$ & NS & \\
\hline NS indicates not significant. & \\
\hline
\end{tabular}

\section{Discussion}

Excessive selenium is toxic to plants and animals. Wang (2012) found that a low concentration of selenite promotes plant growth. However, the plant phenotypes were severely affected as the concentration of selenite increased. When the concentration of selenite was continuously increased to $10 \mathrm{mg} / \mathrm{L}$, the shoot length decreased by $17 \%$, while the root length decreased by $10 \%$. When rice seedlings were treated with $1000 \mu \mathrm{g} / \mathrm{L}$ of selenite and sodium selenate, the growth of roots and stems showed strong inhibition, shortening them significantly (Nothstein et al. 2016). This was in line with our experimental results. However, organic selenium fertilizer did not cause damage to plants even at high concentrations.

Wang (2013b) used a method of foliar application of selenite and increased the yield of rice by 1.24 times. The foliar application of selenite at $75 \mathrm{~g} \mathrm{ha}^{-1}$ increased the rice yield by $5 \%$, along with a small increase in the biomass (Deng et al. 2017). However, the foliar application of selenate or selenite did not markedly increase the tuber yield (Zhang et al. 2019), which was also observed in previous studies on maize (Wang et al. 2013a) and rice (Chen et al. 2002). In our study, the selenium content was increased in the grain without affecting the yield. Also, the application of selenium fertilizer led to an increase in the gelatinization consistency of rice, improving its quality. 
The maximum intake of selenium cannot exceed 400 micrograms per day (Pedrero and Madrid 2009). When calculated based on the consumption of $400 \mathrm{~g}$ rice per person per day, rice can be considered a staple food. According to the "health standard of selenium limit in food", the selenium content in the selenium-rich processed rice should be between 0.04 and $0.30 \mathrm{mg} \mathrm{kg}^{-1}$ while the selenium content of grain (finished grain) should be less than or equal to $0.30 \mathrm{mg} \mathrm{kg}^{-1}$. In our experiment, spraying selenite on eating rice made the maximum concentration of selenium $900 \mathrm{ug} \mathrm{kg}^{-1}$, which is already on the verge of danger. Hence, it was difficult for us to effectively control the intake of selenium. Selenium-enriched rice is a dangerous "double-edged sword" (Brozmanová et al. 2010). The selenium content in rice sprayed with organic selenium is sufficient to provide daily intake, with no risk of excessive consumption.

The selenium ingested by the human body can be divided into several fractions, such as the non-bioaccessible fraction that cannot be absorbed and utilized by the human body and the bioavailable fraction that can be absorbed and reached to the systemic circulation. Hence, it can be distributed to organs and tissues, where it can eventually become bioactive (Thiry et al. 2012). Different forms of selenium are present in plants, which mainly include selenite, selenate, selenomethionine, and selenocysteine. Plants absorb external selenium sources, most of which are further converted into selenomethionine and selenocysteine (Zhu et al. 2009). Generally, the inorganic form of selenium is the most harmful to the human body (Hatfield et al. 2014; Yin et al. 2019), while the organic selenium compounds are better absorbed and utilized by humans. SeMeCys is the most effective seleno-compound identified in the reduction of tumors so far (Carey et al. 2012; Ellis and Salt 2003). Therefore, it is important to not only analyze the total selenium concentration in the edible parts of the plants but also identify the different types of selenium forms available to avoid harmful effects on humans. Our study results also agreed with the previous findings (Hu et al. 2018; Liao et al. 2016) of SeMeCys being not detected in the rice sprayed with selenite. However, SeMeCys was found in brown rice sprayed with Se-AAF, which could be an impactful way to provide human selenium requirements.

Economically, the cost of Se-AAF is 6.5 times more than that of the selenite for $30 \mathrm{~g} \mathrm{ha}^{-1}$. However, given the severe toxicity of selenite, it is not safe to configure the selenium working fluid when the Se-AAF rice is more likely to control the human intake of selenium. To ensure safety in production, organic selenium fertilizer should be used more widely.

\section{Conclusion}

The distribution and accumulation of selenium in rice plants are different for different selenium fertilizers and different selenium spraying time points. Generally, the appropriate selenium release time can be postponed to enrich the selenium content in the grains. The Se concentration is found to be similar between two organic selenium fertilizers. Irrespective of the total selenium, protein selenium, and organic selenium, no significant differences were found between the fermented Se and Se-AAF. Even after spraying the same concentration of selenite, the selenium content in brown rice was higher than the other two organic selenium fertilizers. However, all reached a selenium concentration of more than $200 \mu \mathrm{g} \mathrm{kg}^{-1}$. The hydroponics experiment proved that the organic selenium fertilizer is safe and harmless, with no side effects on the growth of the plant. Hence, we conclude that the usage of organic selenium fertilizer is a better choice for the food Se supplementation.

\section{Declarations}

\section{Funding}


This research was funded by National Rice Industrial Technology System (CARS-01-07); Fundamental Research Funds for the Central Universities (2042017 kf0236), and National Key Research and Development Project (2021YFE0101000) in China.

\section{Conflicts of interest}

The authors have no conflicts of interest to declare that are relevant to the content of this article.

\section{Availability of data and material}

All data generated or analysed during this study are included in this published article.

\section{Code availability}

Not applicable.

\section{References}

1. Bañuelos GS, Stushnoff C, Walse SS, Zuber T, Yang SI, Pickering IJ, Freeman JL (2012) Biofortified, selenium enriched, fruit and cladode from three Opuntia Cactus pear cultivars grown on agricultural drainage sediment for use in nutraceutical foods. Food Chem 135:9-16. https://doi.org/10.1016/j.foodchem.2012.04.021

2. Boldrin PF, Faquin V, Ramos SJ, Boldrin KVF, Ávila FW, Guilherme LRG (2013) Soil and foliar application of selenium in rice biofortification. J Food Compost Anal 31:238-244. https://doi.org/10.1016/j.jfca.2013.06.002

3. Brozmanová J, Mániková D, Vlčková V, Chovanec M (2010) Selenium: a double-edged sword for defense and offence in cancer. Arch Toxicol 84:919-938. https://doi.org/10.1007/s00204-010-0595-8

4. Carey AM, Lombi E, Donner E, de Jonge MD, Punshon T, Jackson BP, Guerinot ML, Price AH, Meharg AA (2012) A review of recent developments in the speciation and location of arsenic and selenium in rice grain. Anal Bioanal Chem 402:3275-3286. https://doi.org/10.1007/s00216-011-5579-x

5. Chen L, Yang F, Xu J, Hu Y, Hu Q, Zhang Y, Pan G (2002) Determination of selenium concentration of rice in china and effect of fertilization of selenite and selenate on selenium content of rice. J Agric Food Chem 50:5128-5130. https://doi.org/10.1021/jf0201374

6. Combs GF Jr (2001) Selenium in global food systems. Br J Nutr 85:517-547. https://doi.org/10.1079/bjn2000280

7. Deng X, Liu K, Li M, Zhang W, Zhao X, Zhao Z, Liu X (2017) Difference of selenium uptake and distribution in the plant and selenium form in the grains of rice with foliar spray of selenite or selenate at different stages. Field Crops Research 211:165-171. https://doi.org/10.1016/j.fcr.2017.06.008

8. Dumont E, Vanhaecke F, Cornelis R (2006) Selenium speciation from food source to metabolites: a critical review. Anal Bioanal Chem 385:1304-1323. https://doi.org/10.1007/s00216-006-0529-8

9. Eich-Greatorex S, Sogn TA, Øgaard AF, Aasen I (2007) Plant availability of inorganic and organic selenium fertiliser as influenced by soil organic matter content and pH. Nutr Cycl Agroecosyst 79:221-231

10. Ellis DR, Salt DE (2003) Plants, selenium and human health. Curr Opin Plant Biol 6:273-279. https://doi.org/10.1016/s1369-5266(03)00030-x

11. Fang Y, Zhang Y, Catron B, Chan Q, Hu Q, Caruso JA (2009) Identification of selenium compounds using HPLCICPMS and nano-ESI-MS in selenium-enriched rice via foliar application. J Anal At Spectrom 24:1657-1664. https://doi.org/10.1039/B912538H 
12. Fordyce F (2007) Selenium geochemistry and health. Ambio 36: 94-97. https://doi.org/10.1579/00447447(2007)36[94:sgah]2.0.co;2

13. Giacosa A, Faliva MA, Perna S, Minoia C, Ronchi A, Rondanelli M (2014) Selenium fortification of an Italian rice cultivar via foliar fertilization with sodium selenate and its effects on human serum selenium levels and on erythrocyte glutathione peroxidase activity. Nutrients 6:1251-1261. https://doi.org/10.3390/nu6031251

14. Goldhaber SB (2003) Trace element risk assessment: essentiality vs. toxicity. Regul Toxicol Pharmacol 38:232242. https://doi.org/10.1016/s0273-2300(02)00020-x

15. Hartfiel W, Bahners N (1988) Selenium deficiency in the Federal Republic of Germany. Biol Trace Elem Res 15:112. https://doi.org/10.1007/bf02990123

16. Hatfield DL, Tsuji PA, Carlson BA, Gladyshev VN (2014) Selenium and selenocysteine: roles in cancer, health, and development. Trends Biochem Sci 39:112-120. https://doi.org/10.1016/j.tibs.2013.12.007

17. Hu Z, Cheng Y, Suzuki N, Guo X, Xiong H, Ogra Y (2018) Speciation of Selenium in Brown Rice Fertilized with Selenite and Effects of Selenium Fertilization on Rice Proteins. Int J Mol Sci 19.

https://doi.org/10.3390/ijms19113494

18. Keskinen R, Räty M, Yli-Halla M (2011) Selenium fractions in selenate-fertilized field soils of Finland. Nutr Cycl Agroecosyst 91:17-29. https://doi.org/10.1007/s10705-011-9435-3

19. Liao G, Xu Y, Chen C, Wu Q, Feng R, Guo J, Wang R, Ding Y, Sun Y, Xu Y, Xia W, Fan Z, Mo L (2016) Root application of selenite can simultaneously reduce arsenic and cadmium accumulation and maintain grain yields, but show negative effects on the grain quality of paddy rice. J Environ Manage 183:733-741. https://doi.org/10.1016/j.jenvman.2016.09.031

20. Liu X, Zhao Z, Duan B, Hu C, Zhao X, Guo Z (2015) Effect of applied sulphur on the uptake by wheat of selenium applied as selenite. Plant Soil 386:35-45

21. Monsen ER (2000) Dietary reference intakes for the antioxidant nutrients: vitamin C, vitamin E, selenium, and carotenoids. J Am Diet Assoc 100:637-640. https://doi.org/10.1016/s0002-8223(00)00189-9

22. Nothstein AK, Eiche E, Riemann M, Nick P, Winkel LH, Göttlicher J, Steininger R, Brendel R, von Brasch M, Konrad G, Neumann T (2016) Tracking Se Assimilation and Speciation through the Rice Plant - Nutrient Competition, Toxicity and Distribution. PLoS ONE 11:e0152081. https://doi.org/10.1371/journal.pone.0152081

23. Pedrero Z, Madrid Y (2009) Novel approaches for selenium speciation in foodstuffs and biological specimens: a review. Anal Chim Acta 634:135-152. https://doi.org/10.1016/j.aca.2008.12.026

24. Rayman MP (2008) Food-chain selenium and human health: emphasis on intake. Br J Nutr 100:254-268. https://doi.org/10.1017/s0007114508939830

25. Ros G, Van Rotterdam A, Bussink D, Bindraban P (2016) Selenium fertilization strategies for bio-fortification of food: an agro-ecosystem approach. Plant Soil 404:99-112. https://doi.org/10.1007/s11104-016-2830-4

26. Schwarz K, Foltz CM (2009) Selenium as an integral part of factor 3 against dietary necrotic liver degeneration. Nutr Rev 36:338-340

27. Souza D, Sbardelotto AF, Ziegler DR, Marczak LD, Tessaro IC (2016) Characterization of rice starch and protein obtained by a fast alkaline extraction method. Food Chem 191:36-44.

https://doi.org/10.1016/j.foodchem.2015.03.032

28. Sun M, Liu G, Wu Q (2013) Speciation of organic and inorganic selenium in selenium-enriched rice by graphite furnace atomic absorption spectrometry after cloud point extraction. Food Chem 141:66-71.

https://doi.org/10.1016/j.foodchem.2013.03.002

Page $17 / 21$ 
29. Thiry C, Ruttens A, De Temmerman L, Schneider Y-J, Pussemier L (2012) Current knowledge in species-related bioavailability of selenium in food. Food Chem 130:767-784. https://doi.org/10.1016/j.foodchem.2011.07.102

30. Valdiglesias V, Pásaro E, Méndez J, Laffon B (2010) In vitro evaluation of selenium genotoxic, cytotoxic, and protective effects: a review. Arch Toxicol 84:337-351. https://doi.org/10.1007/s00204-009-0505-0

31. Wang D, Dinh QT, Anh Thu TT, Zhou F, Yang W, Wang M, Song W, Liang D (2018) Effect of selenium-enriched organic material amendment on selenium fraction transformation and bioavailability in soil. Chemosphere 199:417-426. https://doi.org/10.1016/j.chemosphere.2018.02.007

32. Wang J, Wang Z, Mao H, Zhao H, Huang D (2013a) Increasing Se concentration in maize grain with soil- or foliar-applied selenite on the Loess Plateau in China. Field Crops Research 150:83-90. https://doi.org/10.1016/j.fcr.2013.06.010

33. Wang YD, Wang X, Ngai SM, Wong YS (2013b) Comparative proteomics analysis of selenium responses in selenium-enriched rice grains. J Proteome Res 12:808-820. https://doi.org/10.1021/pr300878y

34. Wang YD, Wang X, Wong YS (2012) Proteomics analysis reveals multiple regulatory mechanisms in response to selenium in rice. J Proteomics 75:1849-1866. https://doi.org/10.1016/j.jprot.2011.12.030

35. Winkel LH, Johnson CA, Lenz M, Grundl T, Leupin OX, Amini M, Charlet L (2012) Environmental selenium research: from microscopic processes to global understanding. Environ Sci Technol 46:571-579. https://doi.org/10.1021/es203434d

36. Xia J, Wishart DS (2011) Web-based inference of biological patterns, functions and pathways from metabolomic data using MetaboAnalyst. Nat Protoc 6:743-760. https://doi.org/10.1038/nprot.2011.319

37. Yin H, Qi Z, Li M, Ahammed GJ, Chu X, Zhou J (2019) Selenium forms and methods of application differentially modulate plant growth, photosynthesis, stress tolerance, selenium content and speciation in Oryza sativa L. Ecotoxicol Environ Saf 169:911-917. https://doi.org/10.1016/j.ecoenv.2018.11.080

38. Zhang H, Zhao Z, Zhang X, Zhang W, Huang L, Zhang Z, Yuan L, Liu X (2019) Effects of foliar application of selenate and selenite at different growth stages on Selenium accumulation and speciation in potato (Solanum tuberosum L.). Food Chem 286:550-556. https://doi.org/10.1016/j.foodchem.2019.01.185

39. Zhu YG, Pilon-Smits EA, Zhao FJ, Williams PN, Meharg AA (2009) Selenium in higher plants: understanding mechanisms for biofortification and phytoremediation. Trends Plant Sci 14:436-442. https://doi.org/10.1016/j.tplants.2009.06.006

\section{Figures}



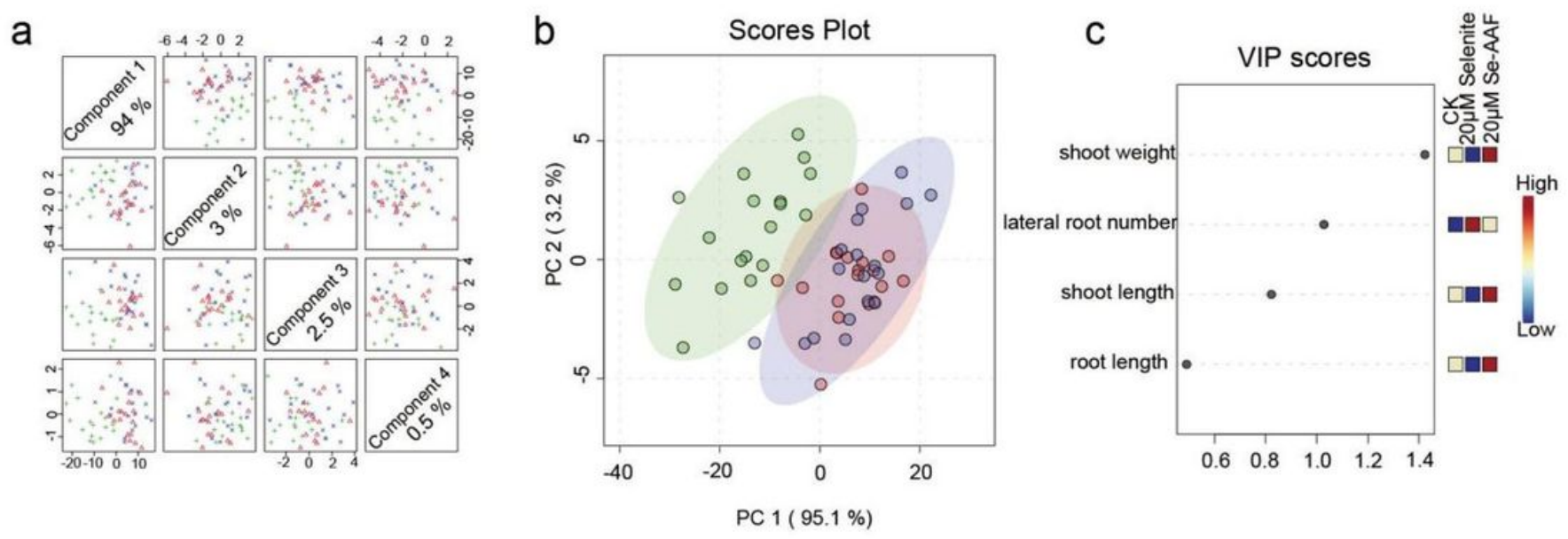

\section{Figure 1}

PLS-DA and PCA analysis of the rice seedling traits of LY9348 after 2 weeks of hydroponic culture in response to different treatments. Distribution of the three treatments in LY9348 rice variety. To distinguish different selenium fertilizers, PLS-DA was performed using four traits. Pairwise score plots between the top four components of PLS-DA are shown here. Green crisscrosses represent seedlings with $20 \mu \mathrm{M}$ selenite treatment while the red triangles represent the control experiment, and the blue multiplication sign represents $20 \mu \mathrm{M}$ Se-AAF treatment (a), $2 \mathrm{~d}$ score plots of PCA. The green circle represents seedlings with $20 \mu \mathrm{M}$ selenite sodium treatment, while the red circle represents the control experiment. The blue circle indicates $20 \mu \mathrm{M}$ Se-AAF treatment (b), VIP scores (c). 

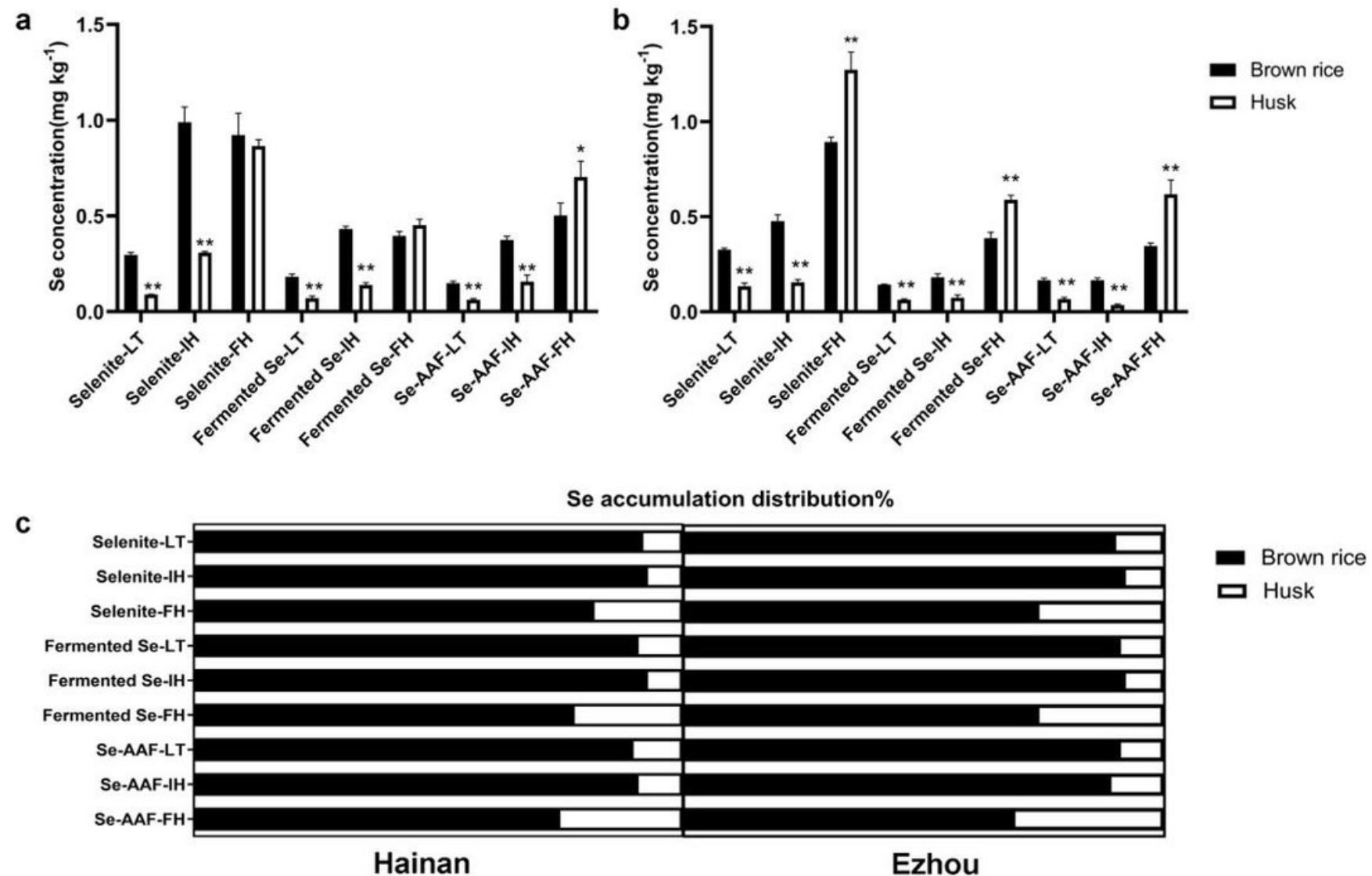

Figure 2

Se concentration and distribution in the grains with foliar spray of selenite, fermented Se, or Se-AAF during late tillering $(\mathrm{LT})$, initiate heading $(\mathrm{IH})$, and full heading $(\mathrm{FH})$ stages. Se concentration in brown rice and husk in Hainan (a), Se concentration in brown rice and husk in Ezhou (b). Se accumulation and distribution in the grains (c). Asterisks show significant differences between brown rice and husk during the $\mathrm{LT}, \mathrm{IH}$, and FH stages when applied with foliar spray of selenite, fermented Se, or Se-AAF. ( $\left.{ }^{\star} \mathrm{p} \otimes 0.05,{ }^{* \star} \mathrm{p} \otimes 0.01\right)$. Data are represented as means \pm SE.

a

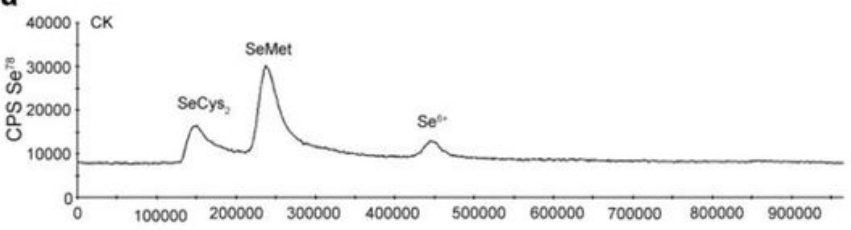

C

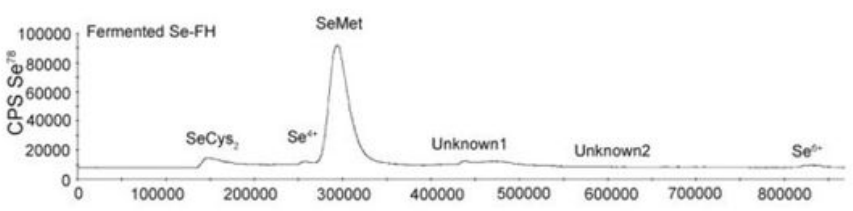

b

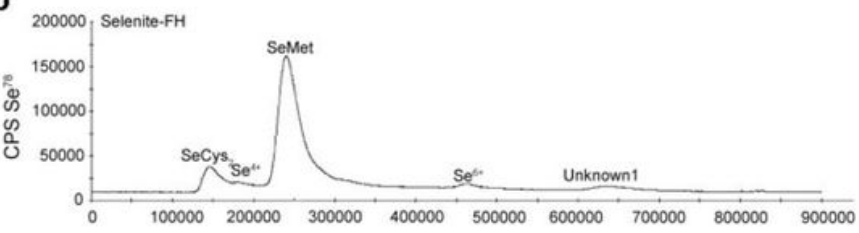

d

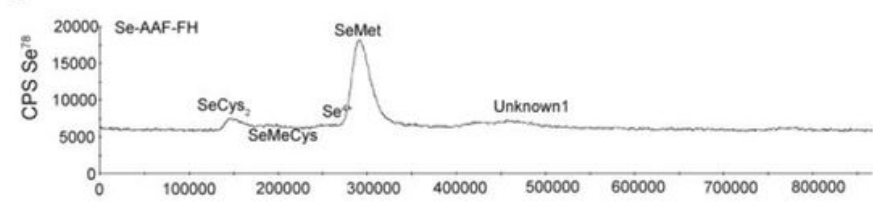


Figure 3

HPLC-ICP-MS chromatograms of the enzymatic extract of brown rice after the foliar application of selenite, fermented Se, or Se-AAF during the full heading stage.

a

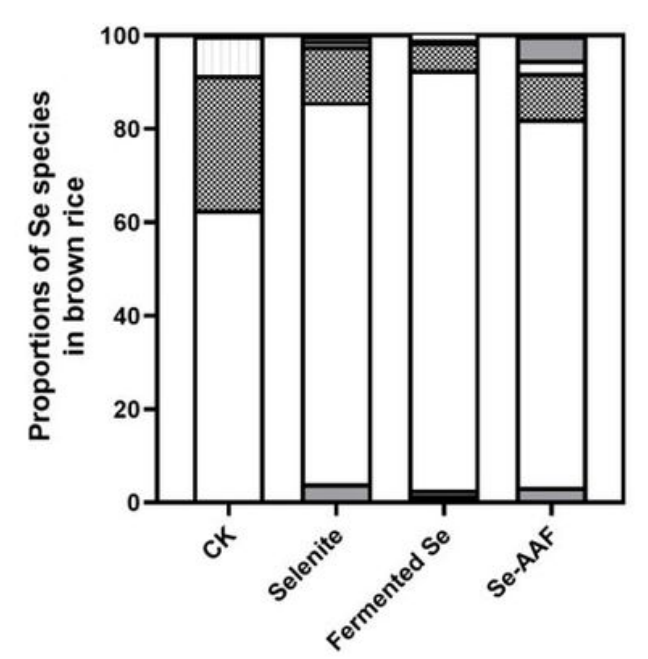

b

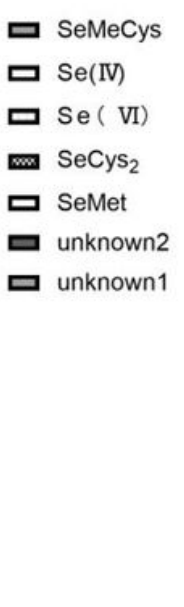

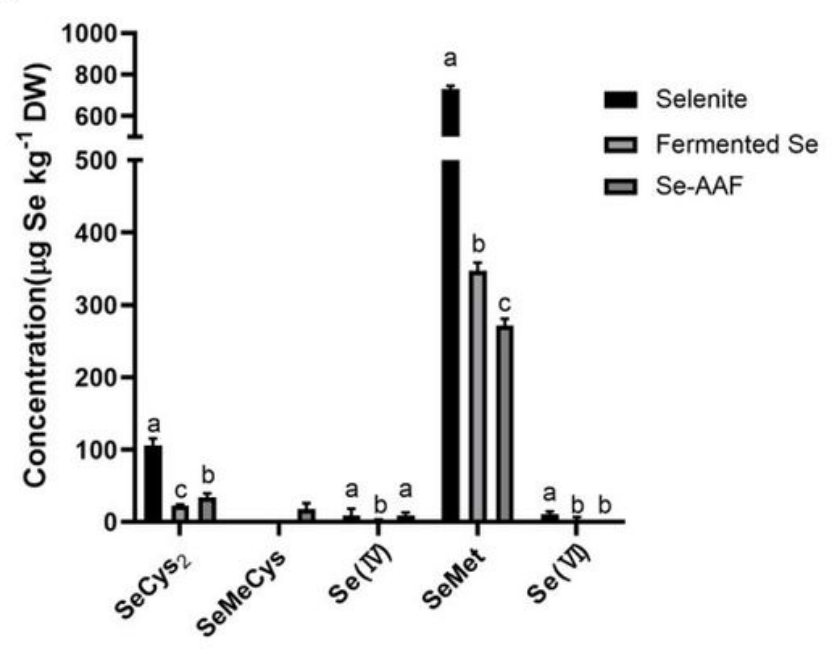

\section{Figure 4}

Proportions of Se species in the grain of LY9348 when applied with foliar spray of selenite, fermented Se, or Se-AAF at the FH growth stage, determined by HPLC-ICP-MS (a) Selenium species concentration in the grains applied with foliar spray of selenite, fermented Se, or Se-AAF at the FH growth stage (b). Different letters indicate significant differences among selenite, fermented Se and SeAAF treatments of the same Se species at pष0.05. Data are represented as means $\pm S E(n=3)$. 